\title{
Factors responsible for early and forced marriage in Iran
}

\author{
Hossein Matlabi ${ }^{1,}{ }^{*}$, Ahmad Rasouli ${ }^{2}$, Hamidreza Hamedi Behtash ${ }^{2}$, Ali Faraghi Dastjerd ${ }^{2}$, \\ Behnaz Khazemi ${ }^{2}$ \\ ${ }^{1}$ Dept of Health Education and promotion, Faculty of Health Sciences, Tabriz University of Medical Sciences, Tabriz, Iran \\ ${ }^{2}$ Student Research Committee, Tabriz University of Medical Sciences, Tabriz, Iran
}

\section{Email address:}

matlabih@tbzmed.ac.ir (H. Matlabil)

\section{To cite this article:}

Hossein Matlabi, Ahmad Rasouli, Hamidreza Hamedi Behtash, Ali Faraghi Dastjerd, Behnaz Khazemi. Factors Responsible for Early and Forced Marriage in Iran. Science Journal of Public Health. Vol. 1, No. 5, 2013, pp. 227-229. doi: 10.11648/j.sjph.20130105.17

\begin{abstract}
Child marriage directly impact girls' education, health, psychological well-being, and the health of their offspring. This qualitative study was carried out to investigate the causes of this silent health issue in village of Hervi, Tabriz, Iran. Data was collected by participating 60 students and their parents using focus group discussions and interviews and then analysed by applying content analysis. Results showed that the most important reason was cultural, traditional issues which driven by poverty and low awareness of the respondents about risk of child marriage. One of the most effective methods of reducing child marriage and its health consequences is mandating that girls stay in school.
\end{abstract}

Keywords: Child Marriage, Forced Marriage, Tabriz, Iran

\section{Introduction}

Child marriage, defined as a formal marriage or informal union before age 18 , is a reality for both boys and girls, although girls are disproportionately the most affected. About a third of women aged 20-24 years old in the developing world were married as children. Child marriage is most common in South Asia and Sub-Saharan Africa, but there are big differences in prevalence among countries of the same region. While data from 47 countries show that, overall, the median age at first marriage is gradually increasing. This improvement has been limited primarily to girls of families with higher incomes [1, 2].

According to Sharia law boys in the 15 years and girls at the age of 9 become sexually mature [3]. Based on Iranian civil law, minimum marriage age for girls is 13 and 15 years for boys. Adult warrant also can be issued by a judge asking a few questions before the age of 13[4].

Results of studies have confirmed that because girls do not mature physically at an early age, married people can get the physical problems and mood disorders depression anxiety disorders and obsessive and make dismay [5]. Iron and calcium deficiency is very common in girls under 18 years of age and pregnancy on the risk of osteoporosis and anaemia in them increases [6, 7]. According to experts, the first year of marriage increases the risk of Cervical Cancer $[8,9]$.
Although normal pregnancy is associated with a feeling of great satisfaction and fulfilment, but pregnancy less than 18 years is one of the risk factors that put a person at risk of high-risk pregnancy. Adolescents Pregnancy is a risk for two reasons:

A: The lack of information on juvenile for necessary care during pregnancy and infant care; B) Lack of partner knowledge about these cares. New born infants whose mothers suffer from early and forced marriage are at risk of low birth weight, malnutrition and disability [10].

International human rights organizations have warned about the increasing number of brides who are aged less than 18 years. In 2010, 67 million women 20-24 around the world had been married before the age of 18 . The number of children who enter into marriage or cohabitation each year varies according to region and across countries while countries with the highest prevalence of child marriage are concentrated in Western and Sub-Saharan Africa, due to population size, the largest numbers of child brides reside in South Asia [11, 12].

Among all developed countries, America has the highest teen pregnancy rate. Every year more than 1.1 million children became pregnant and their delivery will include approximately 295 total births. One out of every 10 American girls at 15-19 years old has experienced pregnancy which $95 \%$ of them are junk [13]. According to 
the United Nations, In Afghanistan now nearly $75 \%$ of Afghan girls are forced married before the age of 16 that $45 \%$ of them has done at $13-15$ years old[14].

According to the results of Iranian studies, more than $7.7 \%$ of girls in Tehran and $40 \%$ in Sistan and Baluchestan states were forced marriage before age of 18 . It has also been also well known that $16 \%$ of married females were in the age group of 15-19 years. The figure for the whole country in rural and urban areas has been reported $19.6 \%$ and $13.7 \%$ respectively. Furthermore, education had a meaningful relation with child marriage whereas marriage rate were high amongst illiterate youth $[15,16]$.

Given the above, this study carried out to determine the cause of the marriage under 18 years in the Hervi village of Tabriz city in Iran

\section{Methodology}

\subsection{Method and Sampling}

A qualitative study was designed and data was gathered by individual interviews and applying focus group discussions with 60 participants. The following groups were identified:
A) Parents of girls married below 18 years;
B) Married student;
C) Single students;
D) Teachers of school and health care staffs;
E) Residents of village.

\subsection{Procedure}

School Manager was contacted for permission to use the school for fieldwork. Other groups were also invited to take part by teachers and health care centre. The interviews based on semi- structured questionnaire took approximately 30 minutes. An information sheet was used to provide potential participants with facts about the study. Interviews and discussion groups were defined by asking simple questions and then continued with more complex questions that include:

1) The general opinion of people about marriage and the appropriate time;

2) Age of marriage for girls in the village;

3) Factors affecting girl's marriage (family obligation and desire of girls);

4) Effect of levels of literacy and knowledge on marriage and cohabitation;

5) Information about dangers of early and enforced marriage;

6) Asking the girls about their goals and dreams in life.

\section{Results and Discussion}

Results showed that the most important reasons of forced and child marriage could be categorised as follow:

A) Following the village culture and social pressure;

B) Economic Issues;
C) Lack of awareness about side effects of child marriage;

D) Negative attitude toward continuing of education in high schools;

E) Tend to marry young boys in early ages;

F) Freedom from undesirable and rigid rules of parents applying to girls;

G) Lack of access to high school in the area.

The residents of village have got an opinion that girls should marry before age of 15 . Chances of a successful marriage will dramatically reduce after this golden age. The people also suppose that unmarried girls may have physical or sexual problems. These social difficulties and mentality make up the family of a 7-8 year old girl think their girl should marry soon. This habit has been significantly became a competitive issue among families and even methods of intellectual maturity of students who have not reached their influence eager and interested in the marriage age. At this case, a mother of 21 years girls was upset that her daughter is 21 years old and still unmarried. This woman was very concerned that her daughter would be lucky if she get marry.

Regarding to financial issues, also the most residents were relatively in good situation, the economy position was one of the main causes of early marriage of girls. Those family have good financial situations would like to choice their bride from wealthy family. Poor families also have girls would desire to hunt a rich boy. Wealthy groom may guarantee their future from unstable economic situations and fix the problems and hardships parents have suffered in life. One of my students told me that "...you'll be lucky to marry this person because of his financial position. I wish".

Furthermore, a mother stated that "families sell their girls to make money", "because money is not important for me, I allow my daughter to continue her education and get marry with educated boy and her favourite man."

Ignorance and lack of information of family members and students about life skills, marriage and cohabitation is another problem that makes it difficult to reduce forced marriage ratio. Students also who are not yet mature and intellectual, would adopt the ways and methods of their mothers in their life.

A teacher stated that "students look very happy for the purchase of cloths and gold with and show others, however, that even some of them do not know who are married. Only 1 or 2 students complained about their marriage ".

Lack of access to high school was one of the main reasons that students could not continue their education. Disapproval of fathers and brothers with education of girls in high schools may connect to financial issues as well as traveling to and from school to further education centres.

In these conditions because there is also no attractive entertainment and recreational facilities in village, children reach a stillness in life, a kind of deadlock and apparently they think that marriage is the only way for getting out of this deadlock. One of the students said that "my brother doesn't let me go to further city for continuing my education because their people aren't good and they cause harassment for us". 
Finally, boys tend to marry young girls in rural areas and this causes a kind of fear in families that if their daughters get older, nobody will marry them and this is a shame for families. Some residents in response to this question that how can we prevent early marriage of girls? $r$ that educational classes should be held for boys and ask them not to marry young girls. Few students considered marriage as a great way to escape from unreasonable restrictions of their families.

\section{Conclusion}

Considering this study, the main causes of marriage under age of 18 could be summarised cultural poverty, ignorance of villagers, and lack of power to make decision, low authority and volition of girls. So for changing incorrect beliefs of target group and providing suitable context for continuing studies, appropriate measures should be done by education and healthcare workers. One of the most effective methods of reducing child marriage and its health consequences is mandating that girls stay in school.

\section{Acknowledgements}

It is necessary to appreciate and thank the kindness efforts of health, educational staff and participants.

\section{References}

[1] United Nations Children's Fund. Child protection from violence, exploitation and abuse. New York: United Nations Children's Fund; 2012. Retrieved May 2013 from http://www.unicef.org/protection/57929_58008.html

[2] Nawal MN. Child Marriage: A Silent Health and Human Rights Issue. Rev Obstet Gynecol. 2009; 2(1):51-6.

[3] Rafati A, Criteria for determining maturity stage in Islam. Retrieved June 2013, from http://www.rafatinaeeni.com/Portal/Cultcure/Persian/Catego ryID/14806/CaseID/94958/71243.aspx

[4] Eghlima M, Marriage at an early age is a fact that does not deny, 2010, Retrieved March 2012, from http://iranyar.ir/rony/12249-1389-10-13-06-37-59.html

[5] Le Strat Y, Dubertret C, Le Foll B. Child marriage in the United States and its association with mental health in women. Pediatrics. 2011; 128(3):524-30.

[6] Chaturvedi S, Kapil U, Bhanthi T, Gnanasekaran N, Pandey RM. Nutritional status of married adolescent girls in rural Rajasthan. Indian J Pediatr. 1994; 61(6):695-701.

[7] Rudäng R, Mellström D, Clark E, Ohlsson C, Lorentzon M. Advancing maternal age is associated with lower bone mineral density in young adult male offspring. Osteoporos Int. 2012; 23(2):475-82.

[8] Nour NM. Health consequences of child marriage in Africa. Emerg Infect Dis. 2006; 12(11):1644-9.

[9] Kuhn L, Denny L, Pollack A, Lorincz A, Richart R, Wright T. Human papillomavirus DNA testing for cervical cancer screening in low resource settings. J Natl Cancer Inst. 2000; 92:818-25.

[10] Cunningham F.G, et al., Williams Obstetrics, McGraw-Hill Professional, 21 edition, 2001.

[11] International center for research on women. Child marriage facts and figures. USA: International centre for research on women; 2013.

[12] United Nations Children's Fund. Early marriage a harmful traditional practice. New York(USA): United Nations Children's Fund; 2005.

[13] Neeson J.D. Comprehensive Maternity Nursing: Nursing Process and the Childbearing Family, Lippincott Williams \& Wilkins, 1986.

[14] Women and Children Legal Research Foundation. Early Marriage in Afghanistan. Deh-Bori: Women and Children Legal Research Foundation; 2008.

[15] Seyf-allahi A. 800 thousand children have been getting married in Iran. Tehran: Tebyan; 2011 [Retrieved July 2012]. Available from: http://www.tebyan.net/newindex.aspx?pid=194704 [In Persian]

[16] Lotfi R. Consequences of early marriage on women's health Women health. 2010; 1(2):67-79 [In Persian]. 